Original Research Paper

\title{
Lignin Content, Ligninase Enzyme Activity and in vitro Digestability of Sugarcane Shoots using Pleurotus ostreatus and Aspergillus oryzae at Different Fermentation Times
}

\author{
${ }^{1}$ Roni Pazla, ${ }^{1}$ Novirman Jamarun, ${ }^{1}$ Lili Warly, ${ }^{2}$ Gusri Yanti and ${ }^{3}$ Nur Azijah Nasution \\ ${ }^{I}$ Department of Nutrition Science and Feed Technology, Animal Husbundry Faculty andalas University, Padang, Indonesia \\ ${ }^{2}$ PhD Student of Animal Husbandry Faculty andalas University, Padang, Indonesia \\ ${ }^{3}$ Magister Student of Animal Husbandry Faculty andalas University, Padang, Indonesia
}

\author{
Article history \\ Received: $10-08-2021$ \\ Revised: 09-09-2021 \\ Accepted: 11-09-2021 \\ Corresponding Author: \\ Novirman Jamarun \\ Department of Nutrition \\ Science and Feed Technology, \\ Animal Husbundry Faculty \\ andalas University, Padang, \\ Indonesia \\ Email: novirman55@gmail.com
}

\begin{abstract}
This study aims to obtain the best lignin content, ligninase enzyme activity and in vitro digestibility value of fermented sugarcane shoots using Pleurotus ostreatus and Aspergillus oryzae at different fermentation times. The research process is divided into 2 stages. Stage 1 treatment samples include A1B1 = Sugarcane shoots fermented with Pleurotus ostreatus for 14 days; A1B2 = Sugarcane shoots fermented with Pleurotus ostreatus for 21 days; A1B3 = Sugarcane shoots fermented with Pleurotus ostreatus for 28 days; A2B1 = Sugarcane shoots fermented with Aspergillus oryzae for 14 days; A2B2 = Sugarcane shoots fermented with Aspergillus oryzae for 21 days; A2B 3 = Sugarcane shoots fermented with Aspergillus oryzae for 28 days. The design used is a completely randomized design with a factorial pattern. Stage 2 treatment samples cover A = Sugarcane shoots fermented with Pleorotus ostreatus for 21 days; B = Sugarcane shoots fermented with Pleorotus ostreatus for 28 days; $\mathrm{C}=$ Sugarcane shoots fermented with Aspergillus oryzae for 21 days; $\mathrm{D}=$ Fermented sugarcane shoots with Aspergillus oryzae for 28 days. The design used was a randomized block design. The results showed that there was no interaction between the type of mold and the fermentation time on the lignin content $(\mathrm{P}>0.05)$, but there was an interaction with the enzyme activity of Laccase, LiP and $\mathrm{MnP}(\mathrm{P}<0.05)$. Also, there were significant differences in the digestibility of protein, cellulose, hemicellulose, VFA and $\mathrm{NH}_{3}(\mathrm{P}<005)$, however the digestibility of DM, OM, ADF, NDF and rumen fluid $\mathrm{pH}$ had no significant difference $(\mathrm{P}>0.05)$. It was concluded that sugarcane shoots fermented with Pleurotus ostreatus mold for 28 days got the best results with the value as follow, lignin content (11.55\%), CP digestibility $(57.90 \%)$, cellulose digestibility $(50.25 \%)$, Hemicellulose digestibility $(62.65 \%)$, Laccase enzyme activity $(2.68 \mathrm{U} / \mathrm{mL})$, LiP enzyme activity (19.44 U/mL), VFA (111.67 mM) and $\mathrm{NH}_{3}(10.48 \mathrm{mg} / 100 \mathrm{~mL})$.
\end{abstract}

Keywords: Aspergillus oryzae, Fermentation, Lignin, Pleurotus ostreatus, Sugarcane Shoots

\section{Introduction}

Sugarcane shoots are not widely used by sugar producers. It usually wastes so that it has the potential as a potential ruminant feed provider. Sugarcane is harvested in the dry season. Therefore, it can be used as an alternative feed to replace grass, which in the dry season is very limited in availability. Sugarcane plantations in Indonesia cover an area of 453,328 hectares and produce sugar cane shoots of $30 \%$ (DJP, 2019).
The biggest obstacle in the utilization of sugarcane shoots as ruminant feed is the high lignin content (Susanti et al., 2020). Lignin is a wood substance in plants that cannot be digested and reduced the ability of livestock to consume food (Jamarun et al., 2018). Fermentation technology using microorganisms that produce lignin's enzymes (Laccase, Manganese peroxidase and lignin peroxidase) is one of the most effective solutions to overcome the problem (Jamarun et al., 2017a; Pazla et al., 2020). 
Pleurotus ostreatus and Aspergillus oryzae molds are microorganisms that produce ligninase enzymes which are effective in degrading lignin (Zhang et al., 2015; Dimawarnita and Tripanji, 2018). The effectiveness of this molds are largely determined by the incubation time and the type of material being processed. Anita et al. (2011) reported that bagasse fermented using Pleurotus ostreatus and Phanerochaete chrysosporium for 28 days gave the best results with a lignin degradation value of $24 \%$, while bagasse fermented using Pleurotus ostreatus and Trametes versicolor for 7 days managed to reduce lignin $17.48 \%$. Lignin degradation and ligninase enzyme activity of Aspergillus oryzae were higher than Phanerochyate chrysosporium (Guo et al., 2014).

Fermentation of sugarcane shoots with different types of molds and duration of fermentation will certainly have varying effects on lignin content, ligninase enzyme activity and digestibility values in ruminants, but the extent of the effect is not certainly known. To prove the extent of this influence, it is necessary to conduct in-depth research on ruminants in vitro. This study aims to obtain the best lignin content, ligninase enzyme activity and in vitro digestibility value of fermented sugarcane shoots using Pleurotus ostreatus and Aspergillus oryzae at different fermentation times.

\section{Materials and Methods}

This research was divided into 2 experimental stages. The first stage is fermentation of sugarcane shoots with Pleurotus ostreatus and Aspergillus oryzae at different fermentation times to see the level of lignin content and ligninase enzyme activity. The second stage is the digestibility and fermentability test of the rumen fluid from the best fermented sugarcane shoots was carried out in stage 1 using in vitro techniques.

\section{Experimental Site}

This research was carried out in three laboratories which are at the ruminant nutrition laboratory, the feed industry technology laboratory and the biotechnology laboratory at the Faculty of Animal Husbandry andalas University, Padang, West Sumatra, Indonesia. Sugarcane shoots samples were taken from sugarcane plantations, Koto Lalang area, Kuranji, Padang.

\section{Research Material}

The materials used in this study covers Pleurotus ostreatus mold, Aspergillus oryzae mold, Potato Dextrose Agar (PDA) medium, sugarcane shoots, aquades, reagents (to measure the activity of ligninase enzymes such as ABTS), guaiacol and veratryl alcohol, rumen fluid, Mc. Dougalls, $\mathrm{H}_{2} \mathrm{SO}_{4}$, Neutral Detergent
Fiber (NDF) solution, Acid Detergent Fiber (ADF) solution and rumen fluid from goat.

The equipment used is a set of equipment for rejuvenation of molds, which includes autoclave, glass beaker, cotton, aluminum foil, test tube, analytical balance, $\mathrm{pH}$ meter, plastic and pipette.

\section{Research Methods}

The research is divided into 2 stages as follow:

1. Research Stage I (fermentation of sugarcane shoots with Pleurotus ostreatus and Aspergillus oryzae at different fermentation times)

\section{Parameters measured}

The variables observed were lignin content after fermentation and ligninase enzyme activity consisting of laccase, Lignin Peroxidase (LiP) and manganese peroxidase (MnP).

\section{b. Research Implementation}

Samples of sugarcane shoots were taken as much as 15 $\mathrm{kg}$. The sugarcane shoots were chopped $3-5 \mathrm{~cm}$ and dried in the sun for 2 days to reach $10 \%$ moisture content, then ground using a grinder into flour.

Pleurotus ostreatus and Aspergillus oryzae were rejuvenated on PDA media and incubated for 7 days at $30^{\circ} \mathrm{C}$. Then, a total of 100 grams of crushed sugarcane shoots are put into plastic and add $50 \%$ aquadest until the water content reaches $60 \%$. After the medium cooled, the Pleurotus ostreatus and Aspergillus oryzae were inoculated with test tube $\left(5 \times 10^{6} \mathrm{cfu} / \mathrm{ml}\right)$ each which had been grown which then being incubated for 14, 21 and 28 days. After reaching the appropriate day for the treatment, the medium was ready to be harvested and the fresh weight was weighed, then put in the oven to dry at a temperature of $60^{\circ} \mathrm{C}$. If it is dry, the medium is stored to be used as a test sample for the lignin contents, activity of the ligninase enzyme and material for the implementation of the second stage of research, namely in vitro Table 1 and 2 .

Table 1: Chemical composition of sugarcane shoots before fermentation

\begin{tabular}{ll}
\hline Chemical composition & \%DM \\
\hline Dry matter & $89.35 \pm 0.123$ \\
Ash & $8.43 \pm 0.123$ \\
Organic matter & $91.57 \pm 0.219$ \\
Crude protein & $5.68 \pm 0.253$ \\
NDF & $57.13 \pm 0.342$ \\
ADF & $45.71 \pm 0.251$ \\
Cellulose & $28.21 \pm 0.235$ \\
Hemicellulose & $11.41 \pm 0.251$ \\
Lignin & $15.05 \pm 0.234$ \\
Silica & $4.81 \pm 0.172$ \\
\hline
\end{tabular}


Table 2: Chemical composition of sugarcane shoots after fermentation of each treatment (\% DM)

\begin{tabular}{|c|c|c|c|c|c|c|}
\hline \multirow{2}{*}{$\begin{array}{l}\text { Chemical } \\
\text { composition }\end{array}$} & \multicolumn{6}{|c|}{ Treatments } \\
\hline & A1B1 & A1B2 & A1B3 & $\mathrm{A} 2 \mathrm{~B} 1$ & $\mathrm{~A} 2 \mathrm{~B} 2$ & $\mathrm{~A} 2 \mathrm{~B} 3$ \\
\hline Dry matter & 92.77 & 91.75 & 91.15 & 93.27 & 92.24 & 91.49 \\
\hline Organic matter & 90.17 & 89.64 & 90.10 & 90.51 & 90.39 & 89.94 \\
\hline Crude protein & 7.90 & 8.10 & 8.56 & 7.73 & 8.43 & 7.84 \\
\hline $\mathrm{ADF}$ & 62.28 & 56.20 & 50.20 & 62.94 & 52.19 & 61.70 \\
\hline Cellulose & $44,98.00$ & 40.72 & 35.01 & 45.01 & 36.28 & 39.68 \\
\hline NDF & 71.63 & 69.94 & 67.93 & 72.75 & 69.18 & 71.06 \\
\hline Hemicellulose & 9.35 & 13.74 & 17.72 & 9.81 & 16.99 & 9.36 \\
\hline Ash & 9.49 & 9.69 & 9.75 & 10.08 & 10.09 & 10.15 \\
\hline Silica & 96.64 & 96.55 & 96.61 & 96.64 & 96.58 & 96.71 \\
\hline
\end{tabular}

The procedure from (Warishi et al., 1992) was used to test the activity of the MnP enzyme. Two stages of measurement occurred, namely, the measurement following the addition of $\mathrm{Mn}$ and the measurement without the addition of Mn. Measurement upon the addition of $\mathrm{Mn}$ : For this measurement, 0.1 buffer lactate ( $\mathrm{pH} 4.5,50 \mathrm{M}), 0.1 \mathrm{~mL}$ guaiacol $(4 \mathrm{mM}), 0.2 \mathrm{~mL} \mathrm{MnSO}_{4}$, $0.3 \mathrm{~mL}$ Aquades $(1 \mathrm{~mm}), 0.1 \mathrm{~mL} \mathrm{H}_{2} \mathrm{O}_{2}(1 \mathrm{~mm})$ and $0.2 \mathrm{~mL}$ filtrate enzyme were added to a $2 \mathrm{~mL}$ tube for a total volume of $1 \mathrm{~mL}$. The cuvette tube was shaken slowly so that all ingredients were mixed. The enzyme activity reaction was carried out at a temperature of $20 \pm 1^{\circ} \mathrm{C}$. Absorbance was measured at 0 and $30 \mathrm{~min}$ at wavelength $465 \mathrm{~nm}$. Measurement without the addition of Mn: For this measurement, $0.1 \mathrm{~mL}$ buffer lactate $(\mathrm{pH} 4.550 \mathrm{M})$, $0.1 \mathrm{~mL}$ guaiacol $(4 \mathrm{~mm}), 0.5 \mathrm{~mL}$ distilled water, $0.1 \mathrm{~mL}$ $\mathrm{H}_{2} \mathrm{O}_{2}(1 \mathrm{~mm})$ and $0.2 \mathrm{~mL}$ filtrate enzyme were added to a $2-\mathrm{mL}$ tube for a total volume of $1 \mathrm{~mL}$. The cuvette tube was shaken slowly so that all the ingredients were mixed. The enzyme activity reaction was carried out at a temperature of $20 \pm 1^{\circ} \mathrm{C}$. Absorbance was measured at 0 and $30 \mathrm{~min}$ at wavelength of $465 \mathrm{~nm}$. The activity of $\mathrm{MnP}$ is the activity observed upon the addition of $\mathrm{Mn}$ minus the enzyme activity without the addition of $\mathrm{Mn}$.

\section{c. Research design}

The design used is a completely randomized design with a factorial pattern $(2 \times 3 \times 3)$, as follow:

Factor $\mathrm{A}$ is the type of mold:

1. Pleurotus ostreatus (A1)

2. Aspergillus oryzae (A2)

Factor $\mathrm{B}$ is fermentation time:

1. 14 days (B1)

2. 21 days (B2)

3. 28 days (B3)

This design follows the model of (Steel and Torrie 1960). Also, Duncan's Multiple Range Test (DMRT) was used due to the difference of mean treatment value from the analysis of variance.
From the results of the first stage of the research, it was found that the best 4 treatment combinations would be continued in the second phase of the research. The best selection was done based on the lowest lignin content and the highest crude protein after fermentation.

2. Research Stage 2 (The digestibility and fermentability test of the rumen fluid from the best fermented sugarcane shoots was carried out in stage 1 using in vitro techniques).

\section{a. Parameters measured}

The parameters measured were dry matter digestibility, organic matter digestibility, fiber fraction (NDF, ADF, Cellulose, Hemicellulose) digestibility, rumen $\mathrm{pH}$, Volatile Fatty Acids (VFA) and $\mathrm{NH}_{3}$ concentrations.

Formula:

$$
\begin{aligned}
& D M D(\%)=\frac{S W \times D M S-(R W \times D M R-\text { blank })}{S W \times D M S} \times 100 \% \\
& O M D(\%)=\frac{S W \times D M S \times O M S-(R W \times D M R \times O M R-\text { blank })}{S W \times D M S \times O M S} \times 100 \% \\
& N D F D(\%)=\frac{S W \times D M \times N D F S-(R W \times D M \times \% N D F R)}{S W \times D M \times N D F S} \times 100 \% \\
& A D F D(\%)=\frac{S W \times D M \times A D F S-(R W \times D M \times \% A D F R)}{S W \times D M \times \% A D F S} \times 100 \% \\
& C e l D(\%)=\frac{S W \times D M \times C e l S-(R W \times D M \times \% l R)}{S W \times D M \times \% C e l S} \times 100 \%
\end{aligned}
$$

Where, DMD is Dry Matter Digestibility, SW is Sample Weight, DMS is Dry Matter Sample, RW is Residual Weight, DMR is Dry Matter Residual, OMD is Organic Matter Digestibility, OMS is Organic Matter Sample, OMR is Organic Matter Residual, NDFD is NDF Digestibility, NDFS is NDF sample, NDFR is NDF 
residual, ADFD is ADF digestibility, ADFS is ADF sample, ADFR is ADF residual, CelD is cellulose digestibility, CelS is cellulose sample, CelR is cellulose residual, HemiD is hemicellulose digestibility, HemiS is hemicellulose sample, HemiR is hemicelluloce residual.

\section{b. Research Procedure}

Implementation of in vitro for the measurement of digestibility was carried out following the method of (Tilley and Terry, 1963). Furthermore, the Measurement of $\mathrm{NH}_{3}$ and VFA concentrations was following the (Department of Dairy Science, 1966) procedure.

\section{c. Research design}

The design used was a randomized block design, which consisted of 4 treatments and 3 replications.

The treatments are as follow:

A: Sugarcane shoots fermented with Pleurotus ostreatus for 21 days

B: Sugarcane shoots fermented with Pleurotus ostreatus for 28 days

C: Sugarcane shoots fermented with Aspergillus oryzae for 21 days

D: Sugarcane shoots fermented with Aspergillus oryzae for 28 days

Analysis of variance was used to analyze data based on Steel and Torry (1960). DMRT test was used due to the difference of mean treatment value

\section{Results and Discussion}

Research Stage I

\section{a. Lignin Content}

The average lignin content of sugarcane shoots fermented with Pleurotus ostreatus and Aspergillus oryzae at different fermentation times is presented in Table 3.

Table 3 shows that there is no interaction $(\mathrm{P}>0.05)$ between the type of mold (A) and the length of fermentation (B) on the lignin content of sugarcane shoots, but the type of mold and the fermentation time have a significant effect $(\mathrm{P}<0.05)$ on the content of sugarcane shoots. The lignin content of sugarcane shoots fermented with Aspergillus oryzae was significantly $(\mathrm{P}<0.05)$ higher than that of sugarcane shoots fermented with Pleurotus ostreatus. This condition proves that sugarcane shoots fermented with Pleurotus ostreatus are better in reducing lignin content, which is $19.01 \%$. The low lignin content in sugarcane shoots fermented with Pleurotus ostreatus (12.52\%) showed that the lignin content in sugarcane shoots could be optimally reduced by Pleurotus ostreatus.

The ability of Pleurotus ostreatus and Aspergillus oryzae in degrading sugarcane shoot lignin was still below that of the Phanerochyate chrysosporium mold. Yanti et al. (2021) reported that sugarcane shoots fermented with Phanerochate chrysosporium for 21 days produced a lignin content of $9.89 \%$ with a degradation rate of $34.29 \%$, while sugarcane shoots fermented for 20 days using Pleurotus ostreatus and Aspergillus oryzae only produced lignin content, 12.62 and $13.66 \%$ with lignin degradation rates of 16.15 and $9.24 \%$ respectively. This difference could be caused by the influence of the amount of mold inoculum used in the fermentation process. Similarly, Mirnawati et al. (2013) stated that the amount of inoculum dose added to the substrate will affect the level of degradation of crude fiber.

The duration of fermentation significantly affects the lignin content of sugarcane shoots. Fermentation time of 28 days for both types of mold showed the lowest lignin content of $12.66 \%$. The longer the fermentation time, the higher the level of degradation of the substrate, because the mold needs a carbon source for its growth. The mold fulfills it through the reshuffle of crude fiber (lignin) with the help of the ligninase enzyme (Astuti et al., 2021).

\section{b. Laccase Enzyme Activity}

The average activity of the Laccase enzyme from fermented sugarcane shoots in each treatment is presented in Table 4.

Table 4 shows that there is a significant interaction $(\mathrm{P}<0.05)$ between the type of mold and the time of fermentation on laccase enzyme activity. The activity of the laccase enzyme in A1B3 treatment, namely sugarcane shoots fermented with Pleurotus ostreatus for 28 days was significantly $(\mathrm{P}<0.05)$ higher $(2.68 \mathrm{u} / \mathrm{mL})$ compared to other treatments. This is because the carbon and nitrogen sources in sugarcane shoots are still quite high, so the activity of the laccase enzyme is also high. Similarly, Majeau et al. (2010) stated that the activity of the laccase enzyme is influenced by the availability of carbon and nitrogen sources on the substrate.

\section{c. Lignin Peroksidase Activity}

The average activity of the lignin peroxidase enzyme from fermented sugarcane shoots in each treatment can be Table 5 .

Table 3: The average lignin content of sugarcane shoots fermented with Pleurotus ostreatus and Aspergillus oryzae at different fermentation times (\%)

\begin{tabular}{lllll}
\hline & \multicolumn{3}{l}{ Fermentation time } & \\
Type of mold & B1 & B2 & B3 & Average \\
\hline A1 & 13.39 & 12.62 & 11.55 & $12.52^{\mathrm{B}}$ \\
A2 & 14.43 & 13.66 & 13.78 & $13.96^{\mathrm{A}}$ \\
Average & $13.91^{\mathrm{a}}$ & $13.14^{\mathrm{ab}}$ & $12.66^{\mathrm{a}}$ & \\
\hline
\end{tabular}

Note: Upper case (A, B) and lower case (a, b) are different on the same row and column which indicated significance $(\mathrm{P}<0.05)$ 
Table 4: Laccase enzyme activity of fermented sugarcane shoots in each treatment $(\mathrm{U} / \mathrm{mL})$ Fermentation time

\begin{tabular}{llll} 
Type of mold & $\mathrm{B} 1$ & $\mathrm{~B} 2$ & $\mathrm{~B} 3$ \\
\hline A1 & $1.16^{\mathrm{aA}} \pm 0,55$ & $1.62^{\mathrm{aA}} \pm 0,13$ & $2.68^{\mathrm{aB}} \pm 0.83$ \\
A2 & $1.00^{\mathrm{aA}} \pm 0,01$ & $1.18^{\mathrm{aA}} \pm 0,05$ & $1.32^{\mathrm{bA}} \pm 0.08$
\end{tabular}

Note: Upper case (A, B) and lower case $(\mathrm{a}, \mathrm{b})$ are different on the same row and column which indicated significance $(\mathrm{P}<0.05)$

Table 5: Lignin peroxidase enzyme activity of fermented sugarcane shoots in each treatment $(\mathrm{U} / \mathrm{mL})$

\section{Fermentation time}

\begin{tabular}{llll} 
Type of mold & $\mathrm{B} 1$ & $\mathrm{~B} 2$ & $\mathrm{~B} 3$ \\
\hline A1 & $7.47^{\mathrm{aA}} \pm 0.88$ & $14.34^{\mathrm{aB}} \pm 0.51$ & $19.44^{\mathrm{aC}} \pm 1.45$ \\
A2 & $5.63^{\mathrm{bA}} \pm 0.30$ & $12.68^{\mathrm{aB}} \pm 0.55$ & $10.31^{\mathrm{bC}_{ \pm}} \pm .15$ \\
\hline
\end{tabular}

Note: Upper case (A, B) and lower case (a, b) are different on the same row and column which indicated significance $(\mathrm{P}<0.05)$

The treatment showed a significant interaction $(\mathrm{P}<0.05)$ between the type of mold and the time of fermentation on the activity of the LiP enzyme. Sugarcane shoots fermented with Pleurotus ostreatus for 28 days (A1B3) were significantly higher $(19.44 \mathrm{U} / \mathrm{mL})$ compared to treatments A1B2 (14.34 U/mL), A2B2 (12.68 U/mL), A2B3 (10.31 U/mL), A1B1 $(7.47 \mathrm{U} / \mathrm{mL})$ and A2B1 $(5.63 \mathrm{U} / \mathrm{mL})$. This indicates that sugarcane shoots fermented with Pleurotus ostreatus mold increased as longer fermentation time. Likewise, Dimawarnita (2019) that the LiP enzyme activity of the Pleurotus ostreatus fungus continued to increase until the fifth month. Also, Gomes et al. (2009) added that LiP enzyme activity in Lentinus $s p$ continued to increase in the fifth week.

The activity of the LiP enzyme in this study was higher than that of Puspita (2007), which found a LiP enzyme activity value of $0.430 \mathrm{U} / \mathrm{mL}$ in the wild Pleurotus spp. Cocoa pods fermented with phanerochayte chrysosporium only produced a LiP activity of $0.527 \mathrm{U} / \mathrm{mL}$ (Yakin et al., 2017).

\section{d. Manganese Peroksidase Activity}

The average activity of the manganese peroxidase enzyme from fermented sugarcane shoots in each treatment can be seen in Table 6 .

Table 6 shows that there is a significant interaction $(\mathrm{P}<0.05)$ between the type of mold and the time of fermentation on the activity of the MnP enzyme. MnP enzyme activity in the A2B1 treatment, namely sugarcane shoots fermented with Aspergillus oryzae for 14 days showed the highest MnP activity at $4.60 \mathrm{U} / \mathrm{mL}$ and was not different $(\mathrm{P}>0.05)$ from the MnP activity produced by Pleurotus ostreatus for 14 days of fermentation (A1B1), which was $3.60 \mathrm{U} / \mathrm{mL}$. Optimum $\mathrm{MnP}$ activity in this study was found on day 14. Furthermore, Nurika et al. (2019) reported that $\mathrm{MnP}$ enzyme activity was also optimum on the 14 th day $(0.605 \mathrm{U} / \mathrm{mL})$ of bagasse fermentation by the fungus Phlebia sp.MG-60 and decreased until the 28th day.

$\mathrm{MnP}$ enzyme activity in molds is influenced by availability of nutrients from lignocellulosic degradation (Giardina et al., 2000). The lignocellulose content in the substrate is known to act as an inducer in enzyme production. Inducers are compounds or elements that support reactions in enzymes and support enzyme secretion (Acevedo et al., 2011). Table 6 shows that the longer the fermentation time, the lower the activity of the MnP enzyme produced. It is suspected that the longer the fermentation time, the nutrients needed by the mold in producing MnP enzymes will decrease so that it has an impact on MnP activity. The same happened to Trametes villosa. On the 15th day the fungus showed an increase in MnP activity, while after the 15 th day the activity decreased until it reached 0 on the 30th day (Lordêlo et al., 2014).

\section{Research Stage 2}

\section{a. In vitro digestibility}

The effect of fermented sugarcane shoots with different types of mold and time on in vitro digestibility is presented in Table 7.

Table 7 shows that the treatment had no significant effect $(\mathrm{P}>0.05)$ on DMD, OMD, NDFD and ADFD. The digestibility value of feed is strongly influenced by the lignin content in the feed ingredient. Lignin is the substance that cannot be digested by rumen microbes and blocks the penetration of rumen microbial enzymes to degrade food substances into simple molecules. The lignin content after fermentation in treatments $\mathrm{A}, \mathrm{B}, \mathrm{C}$ and $\mathrm{D}$ was almost the same, which are $12.62,11.55,13.66$ and $13.78 \%$, so that the ability of rumen microbes to degrade feed was also the same. The higher the lignin content in the feed, the lower the digestibility value of the feed.

The same dose of inoculum in each treatment was suspected to be the cause of dry matter digestibility not significantly different between treatments $(\mathrm{P}>0.05)$. Differences in inoculum doses result in differences in the amount of mycelium that was formed so that the degradation of lignin was to be certainly different. A high dose of inoculum allowed more mycelium to be formed so that the mold need more energy. This energy is obtained from the breakdown of cellulose, hemicellulose and lignin substrates as carbon sources (Suharnowo et al., 2012).

Dry matter digestibility in treatment B was higher than the other treatments, although not significantly different (P>0.05) statistically. Dry matter digestibility of sugarcane buds fermented with Pleurotus ostreatus mold for 28 days was $34.16 \%$ higher than treatments A (33.57\%), D (33.09\%) and C (32.71\%). The high dry matter digestibility is due to the accumulation of enzymes produced during the fermentation process. Enzymes 
increased the crude protein content in feed ingredients and dry matter digestibility is also affected by protein levels in feed ingredients. Also, Routa et al. (2015) reported that there is an increase in dry matter digestibility in fermented young coconut coir due to the accumulation of enzymes from white oyster mushrooms. The organic matter digestibility pattern in this study was the same as the dry matter digestibility pattern. The more dry matter digestibility increases, the higher organic matter digestibility improved (Pazla et al., 2018a; Suyitman et al., 2020).

The dry matter digestibility and organic matter of fermented sugarcane shoots in this study were lower than the research by Ay et al. (2018) that obtained DMD and OMD values of 60.2 and $58.2 \%$. However, the result was higher than Elmi (2017) with values of 21.12 and $12.71 \%$. The different value is caused by the difference in the fermentation materials used.

Digestibility of crude protein, cellulose and hemicellulose was significantly affected by treatment $(\mathrm{P}<0.05)$. Treatment $\mathrm{B}$ showed the highest digestibility values for CPD, cellulose digestibility and hemicellulose digestibility was $57.90,50.25,62.65 \%$ respectively. The high crude protein content in treatment $\mathrm{B}$ caused the effectiveness of rumen microbes to utilize protein to form microbial protein to be optimal so that it would increase the rumen microbial population, especially proteolytic bacteria. Pazla et al. (2018b) explained that an increase in the microbial population would increase feed digestibility. The increase in crude protein content was caused by an increase in the mass of mold cells. In addition, Shaba and Baba (2012) stated that the fungus Pleurotus ostreatus also secretes protease enzymes. The secretion of protease enzymes by the fungus Pleurotus ostreatus also plays a role in increasing the protein content of fermented sugarcane shoots so that the absorption of amino acids as the simplest form of protein will be more easily absorbed. According to Mirnawati et al. (2010) mold can increase the protein content of fermented substrate biomass by secreting extracellular enzymes.

The low digestibility of crude protein in sugarcane shoots fermented with Aspergillus oryzae for 21 days (Treatment C) was due to the fact that Aspergillus oryzae with a fermentation period of 21 days had not been able to optimize the growth of mold mycelia so that the enzymes produced were few and caused the process of decreasing lignin not optimally.

$\mathrm{NDF}$ and ADF are fiber fractions from feed consisting of lignin. The digestibility of NDF is higher than the digestibility of ADF because the NDF fraction still contains nutrients that are easily utilized by rumen microbes such as hemicellulose and cell wall proteins, while ADF contains many fractions that are difficult to digest, namely lignin and silica (Jamarun et al., 2017b); (Pazla and Jamarun 2021a). Similarly, Hambakodu et al. (2020) highlighted that lignin levels have a negative correlation with ADF digestibility. The lower the lignin content, the higher the digestibility of ADF. The digestibility of NDF and ADF which did not differ between treatments in this study was also in line with the results of Samadi et al. (2016) who reported that fermentation of sugarcane bagasse for up to 28 days had no significant effect on crude fiber content.

Cellulose and hemicellulose are food substances that was be converted into energy (VFA) by rumen microbes. Low lignin in treatment $\mathrm{B}$ caused rumen microbes, especially cellulolytic bacteria and hemicellulolytic bacteria, to degrade cellulose and hemicellulose more than in other treatments. Hemicellulose was more degraded by rumen microbes than cellulose because cellulose-digesting bacteria also play a role in degrading hemicellulose which causing the digestibility value of hemicellulose to be higher than cellulose.

\section{b. Rumen Fluid Characteristics}

The effect of fermented sugarcane shoots with different types of mold and time on Rumen fluid characteristics is presented in Table 8 . The Table 8 . Shows that the treatment had no significant effect on the $\mathrm{pH}$ of the rumen fluid $(\mathrm{P}>0.05)$. The average value of rumen $\mathrm{pH}$ in this study was still within the normal range which was able to support rumen microbial growth. The ideal rumen $\mathrm{pH}$ range to maintain normal rumen metabolic processes reported by several research results is 6.0-7.0 (Jamarun et al., 2017c; Jamarun et al., 2020).

Fermentation time and different types of molds had a significant effect $(\mathrm{P}<0.05)$ on the total VFA concentration. Sugarcane shoots fermented with pleurotus ostreatus with 28 days of fermentation (Treatment B) showed the highest VFA concentration. VFA concentration decreased in sugarcane shoot fermentation using Aspergillus oryzae on 21 and 28 days $(\mathrm{P}<0.05)$ and there was no significant difference in VFA production in 21-day fermentation using Pleurotus ostreatus (Treatment A).

Table 6: Manganese peroxidase enzyme activity of fermented sugarcane shoots in each treatment $(\mathrm{U} / \mathrm{mL})$

Fermentation time

\begin{tabular}{llll} 
Type of mold & $\mathrm{B} 1$ & $\mathrm{~B} 2$ & $\mathrm{~B} 3$ \\
\hline A1 & $3,60^{\mathrm{aA}} \pm 0,06$ & $2,96^{\mathrm{aA}} \pm 0,90$ & $2,64^{\mathrm{aA}} \pm 0,84$ \\
A2 & $4,60^{\mathrm{aA}_{ \pm}} \pm 0,34$ & $2,00^{\mathrm{aB}_{ \pm}} \pm 0,32$ & $3,74^{\mathrm{aA}_{ \pm}} \pm 0,39$ \\
\hline
\end{tabular}

Note: Upper case $(\mathrm{A}, \mathrm{B})$ and lower case $(\mathrm{a}, \mathrm{b})$ are different on the same row and column which indicated significance $(\mathrm{P}<0.05)$ 
Table 7: In vitro digestibility of fermented sugarcane shoots in each treatment $(\%)$

Treatments

\begin{tabular}{llllll} 
Parameters & A & B & C & D & SEM \\
\hline Dry Matter & 33.57 & 34.16 & 32.71 & 33.09 & 0.76 \\
Organic Matter & 35.21 & 35.49 & 34.00 & 34.45 & 0.75 \\
Crude Protein & $46.54^{\mathrm{b}}$ & $57.90^{\mathrm{a}}$ & $35.86^{\mathrm{d}}$ & $42.16^{\mathrm{c}}$ & 0.98 \\
NDF & 39.81 & 43.72 & 41.13 & 37.20 & 0.63 \\
ADF & 34.42 & 37.03 & 34.39 & 34.78 & 0.71 \\
Cellulose & $45.32^{\mathrm{b}}$ & $50.25^{\mathrm{a}}$ & $40.88^{\mathrm{c}}$ & $33.11^{\mathrm{d}}$ & 0.97 \\
Hemicellulose & $61.89^{\mathrm{a}}$ & $62.65^{\mathrm{a}}$ & $61.86^{\mathrm{a}}$ & $53.18^{\mathrm{b}}$ & 1.28 \\
\hline
\end{tabular}

Note: Means in the same row with different letters (a,b,c,d) are significant $(\mathrm{P}<0.05)$

Table 8: Rumen fluid characteristics of fermented sugarcane shoots in each treatment (\%)

\begin{tabular}{llll}
\hline & Parameters & \\
& $--{ }^{2}$ & & \\
Treatments & $\mathrm{pH}$ & VFA $(\mathrm{mM})$ & $\mathrm{NH}_{3}(\mathrm{mg} / 100 \mathrm{~mL})$ \\
\hline $\mathrm{A}$ & 6.83 & $106.67^{\mathrm{a}}$ & $9.27^{\mathrm{c}}$ \\
$\mathrm{B}$ & 6.86 & $111.67^{\mathrm{a}}$ & $10.48^{\mathrm{d}}$ \\
$\mathrm{C}$ & 6.98 & $86.67^{\mathrm{b}}$ & $8.08^{\mathrm{b}}$ \\
$\mathrm{D}$ & 6.92 & $80.00^{\mathrm{b}}$ & $7.08^{\mathrm{a}}$ \\
SEM & 0.04 & 4.33 & 0.13 \\
\hline
\end{tabular}

Note: Means in the same column with different letters (a,b,c,d) are significance $(\mathrm{P}<0.05)$

The decrease in VFA production in treatments A, C and $\mathrm{D}$ was due to the high content of lignin so that it could not be properly degraded by rumen microbes. In addition, Roni (2018) reported that the high lignin content in the feed even after fermentation would reduce the VFA concentration. The concentration of VFA obtained in this study is still in the normal range according to (McDonald et al., 2010) and (Riestianti et al., 2021), which are $80-160 \mathrm{mM}$ and $107.78-127.14 \mathrm{mM}$.

Ammonia $\left(\mathrm{NH}_{3}\right)$ is the main product of the fermentation of feed protein in the rumen by rumen microbes, where the higher the $\mathrm{NH}_{3}$ concentration, the higher the feed protein undergoes fermentation in the rumen. The $\mathrm{NH}_{3}$ value of the rumen fluid in this study was significantly $(\mathrm{P}>0.05)$ influenced by the treatment. Treatment $\mathrm{B}$ showed the highest concentration of $\mathrm{NH}_{3}$ $(10.48 \mathrm{mg} / 100 \mathrm{~mL})$. The concentration of $\mathrm{NH}_{3}$ in treatment $\mathrm{B}$ was in line with the high crude protein content which was also the highest $(8.56 \%)$ among other treatments. In addition, the lowest lignin content in treatment $\mathrm{B}$ made the protein able to be degraded more by rumen microbes. Liklewise, Pazla and Jamarun (2021b) stated that the high and low concentrations of $\mathrm{NH}_{3}$ are determined by the level of protein in the feed and the degree of degradability of the feed in the rumen. The range of $\mathrm{NH}_{3}$ values obtained in this study was still within the normal range for rumen microbial activity and growth. The minimum concentration of $\mathrm{NH}_{3}$ required for the formation of microbial protein is $5 \mathrm{mg} / 100 \mathrm{~mL}$ (Satter and
Slyter, 1974). $\mathrm{NH}_{3}$ concentration $3.51-4.57 \mathrm{mg} / 100 \mathrm{~mL}$ was still able to maintain the performance of rumen microbes in degrading feed (Jamarun et al., 2021).

\section{Conclusion}

The conclusion of this study was that sugarcane shoots fermented with Pleurotus ostreatus for 28 days produced the lowest lignin content with the highest ligninase enzyme activity, the best in vitro digestibility and optimum rumen fluid characteristics for microbial growth.

\section{Acknowledgement}

This research was carried out with the support and assistance of laboratory technicians at the Faculty of Animal Husbandry andalas University. Special thanks to the Andalas University Research and Community Service Institute for facilitating this research to completion.

\section{Funding Information}

Thank you to the Directorate of Research and Community Service, Ministry of Research and Technology Institutions, Department of the National Research and Innovation Agency for funding this research under contract number 266/SP2H/LT/DPRM/2021.

\section{Author's Contributions}

Roni Pazla: Supervised the conduct of the research, analyzed the data and wrote articles.

Novirman Jamarun: Designed the study.

Lili Warly: edited the article.

Gusri Yanti and Nur Azijah Nasutian: Carried out fermentation and in vitro tests in the laboratory.

\section{Ethics}

This article was written from data from the latest author's research and is original. Corresponding author has ensured that all authors involved in this article have read and approved this article for publication. There are no ethical issues in this study.

\section{References}

Acevedo, F., Pizzul, L., Castillo, M. D. P., Rubilar, O., Lienqueo, M. E., Tortella, G., \& Diez, M. C. (2011). A practical culture technique for enhanced production of manganese peroxidase by Anthracophyllum discolor Sp4. Brazilian Archives of Biology and Technology, 54, 1175-1186. doi.org/10.1590/S1516-89132011000600013

AOAC., 2000. Official Methods of Analysis. Arligton, Virginia, USA.: Association of Analytical Chemists. 
Astuti, T., Jamarun, N., \& Yanti, G. (2021, March). Effect Fermentation of Sugarcane Shoots With Phanerochaete chrysosoporium on the Activity of Lacase Enzymes, Lignin Peroxidase and Manganese Peroxidase. In IOP Conference Series: Earth and Environmental Science (Vol. 709, No. 1, p. 012065). IOP Publishing. doi.org/10.1088/1755-1315/709/1/012065

Ay, A. N., Iskandar, A., \& Marhaeniyanto, E. (2018). Kecernaan Invitro fermentasi pucuk tebu menggunakan urea dan molases. fakultas pertanian, 6(2). https://publikasi.unitri.ac.id/index.php/pertanian/arti cle/view/1320

Anita, S., Heris, E,m Hermiati \& Laksana, R.P.B. (2011). Pengaruh perlakuan pendahuluan dengan kultur campuran jamur pelapuk putih Phanerochaete crysosporium, Pleurotus ostreatus dan Trametes versicolor terhadap kadar lignin. Jurnal Selulosa, 1(2), 81-88. doi.org/10.25269/jsel.v1i02.23

Department of Dairy Science. (1966). General Laboratory Procedures. University of Wisconsin, Madison.

Dimawarnita, F \& Tripanji. (2018). Sintesis karboksimetil selulosa dari sisa baglog jamur tiram (Pleurotus ostreatus). Menara Perkebunan, 86(2), 96-106. doi.org/10.22302/ribb.jur.mp.v86i2.304

Dimawarnita, F. (2019). Aktivitas enzim ligninolitik Pleurotus ostreatus pada media yang mengandung TKKS dan aplikasinya untuk dekolorisasi zat warna (Activity of ligninolytic enzyme of Pleurotus ostreatus on media containing OPEFB and their application for dyes decolorization). E-Journal Menara Perkebunan, 87(1). doi.org/10.22302/iribb.jur.mp.v1i87.328

DJP, 2019. Statistik Perkebunan Indonesia. Sekretariat Direktorat Jendral Perkebunan, Jakarta, Indonesia.

Elmi. (2017). Karakteristik fisik, komposisi nutrien, dan kecernaan in vitro Hi-Fer+ pucuk tebu. Thesis, Institut Pertanian Bogor, Bogor, Indonesia.

Giardina, P., Palmieri, G., Fontanella, B., Rivieccio, V., \& Sannia, G. (2000). Manganese peroxidase isoenzymes produced by Pleurotus ostreatus grown on wood sawdust. Archives of Biochemistry and Biophysics, 376(1), 171-179.

doi.org/10.1006/abbi.1999.1691

Gomes, E., Aguiar, A. P., Carvalho, C. C., Bonfá, M. R. B., Silva, R., \& Boscolo, M. (2009). Ligninases production by Basidiomycetes strains on lignocellulosic agricultural residues and their application in the decolorization of synthetic dyes. Brazilian Journal of Microbiology, 40, 31-39. doi.org/10.1590/S1517-83822009000100005

Guo, D., Zhang, Z., Liu, D., Zheng, H., Chen, H., \& Chen, K. (2014). A comparative study on the degradation of gallic acid by Aspergillus oryzae and Phanerochaete chrysosporium. Water science and technology, 70(1), 175-181. doi.org/10.2166/wst.2014.213
Hambakodu, M., Kaka, A., \& Ina, Y. T. (2020). Kajian In vitro kecernaan fraksi serat hijauan tropis pada media cairan rumen kambing. Jurnal Ilmu Dan Teknologi Peternakan Tropis, 7(1), 29.

https://ojs.uho.ac.id/index.php/peternakantropis/article/view/8907

Jamarun, N., Agustin, F., Pazla, R., \& Oktiacahyani, N. (2017b). Effects of Phosphor (P) Supplementation in Combination with Calcium (Ca) and Manganese (Mn) During Oil Palm Frond Fermentation by Phanerochaete Chrysosporium on Fiber Fractions Content. Proceedings of The $5^{\text {th }}$ International Seminar of Animal Nutrition and Feed Sciences. Matararam, Indonesia, Pp. 200-208.

Jamarun, N., Pazla, R., \& Yanti, G. (2021, April). Effect of boiling on in-vitro nutrients digestibility, rumen fluid characteristics and tannin content of mangrove (Avicennia marina) leaves as animal feed. In IOP Conference Series: Earth and Environmental Science (Vol. 733, No. 1, p. 012106). IOP Publishing. doi.org/10.1088/1755-1315/733/1/012106

Jamarun, N., Pazla, R., Arief, A., Jayanegara, A., \& Yanti, G. (2020). Chemical composition and rumen fermentation profile of mangrove leaves (Avicennia marina) from West Sumatra, Indonesia. Biodiversitas Journal of Biological Diversity, 21(11). doi.org/10.13057/biodiv/d211126

Jamarun, N., Zain, M., Arief., \&Pazla, R. (2017a). Effects of calcium, phosphorus and manganese supplementation during oil palm frond fermentation by Phanerochaete chrysosporium on laccase activity and in vitro digestibility. Pak J Nutr, 16(3), 119-124. doi.org/10.3923/pjn.2017.119.124

Jamarun, N., Zain, M., Arief., \&Pazla, R. (2017c). Effects of calcium (ca), phosphorus (p) and manganese (mn) supplementation during oil palm frond fermentation by phanerochaete chrysosporium on rumen fluid characteristics and microbial protein synthesis. Pakistan Journal of Nutrition, 16 (6): 393399.doi.org/10.3923/pjn.2017.393.399

Jamarun, N., Zein, M., Arief., \& Pazla, R. (2018). Populations of rumen microbes and the in vitro digestibility of fermented oil palm fronds in combination with Tithonia (Tithonia diversifolia) and elephant grass (Pennisetum purpureum). Pak J Nutr, 17(1), 39-45. doi.org/10.3923/pjn.2018.39.45I

Lordêlo.,Silva, M. L. C., de Souza, V. B., da Silva Santos, V., Kamida, H. M., de Vasconcellos-Neto, J. R. T., Góes-Neto, A., \& Koblitz, M. G. B. (2014). Production of manganese peroxidase by Trametes villosa on unexpensive substrate and its application in the removal of lignin from agricultural wastes. Advances in Bioscience and Biotechnology, 5(14), 1067. doi.org/10.4236/abb.2014.514122 
Majeau, J. A., Brar, S. K., \& Tyagi, R. D. (2010). Laccases for removal of recalcitrant and emerging pollutants. Bioresource technology, 101(7), 2331-2350. doi.org/10.1016/j.biortech.2009.10.087

McDonald, P. R., Edwards., J. F. D. Greenhalg, \& Morgan, C. A. (2010). Animal Nutrition. Pearson Education Limited, England, Pp. 90-95

Mirnawati., Djulardi, A., \& Marlida, Y. (2013). Improving the quality of palm kernel cake through fermentation by Eupenicillium javanicum as poultry ration. Pakistan Journal of Nutrition, 12(12), 10851088. doi.org/10.3923/pjn.2013.1085.1088

Mirnawati., Rizal, Y, Marlida, Y, \& Kompiang P.I (2010). The role of humic acid in palm kernel cake fermented by Aspergillus niger for poultry ration. Pakistan Journal of Nutrition, 9(2), 182-85. doi.org/10.3923/pjn.2010.182.185

Nurika, I., Agus, Z. \& Muchlis, N. (2019). Effect of $\mathrm{MnSO}_{4}$ on manganese peroxidase activity in delignification of bagasse by Phlebia Sp. MG-60. Jurnal Teknologi Pertanian. 20 (3), 163-70. doi.org/10.21776/ub.jtp.2019.020.03.3

Pazla, R., \& Jamarun, N. (2021a). Pemanfaatan Pelepah Sawit sebagai Pakan Ternak Ruminansia (In Vitro) Melalui Teknologi Fermentasi Menggunakan Phanerochaete Chrysosporium. LPPM Universitas Andalas, Padang. ISBN-10: 978-623-345-233-5

Pazla, R., \& Jamarun, N. (2021b). Respon Mikroba Rumen terhadap Pemberian Kombinasi Hijauan (Pelepah Sawit Fermentasi, Titonia dan Rumput Gajah). LPPM Universitas Andalas, Padang. ISBN10: 978-623-345-273-1.

Pazla, R., Jamarun, N., Agustin, F., Zain, M., Arief, A., \& Oktiacahyani, N. (2020). Effects of supplementation with phosphorus, calcium and manganese during oil palm frond fermentation by Phanerochaete chrysosporium on ligninase enzyme activity. Biodiversitas Journal of Biological Diversity, 21(5). https://www.smujo.id/biodiv/article/view/4652

Pazla, R., Jamarun, N., Zain, M., \& Arief, A. (2018b). Microbial protein synthesis and in vitro fermentability of fermented oil palm fronds by Phanerochaete chrysosporium in combination with Tithonia (Tithonia diversifolia) and elephant grass (Pennisetum purpureum). Pak. J. Nutr, 17(10), 462470.. doi.org/10.3923/pjn.2018.462.470

Pazla, R., Zain, M., Ryanto, H. I., \& Dona, A. (2018a). Supplementation of minerals (phosphorus and sulfur) and Saccharomyces cerevisiae in a sheep diet based on a cocoa by-product. Pakistan Journal of Nutrition, 17(7), 329-335. doi.org/10.3923/pjn.2018.329.335

Puspita, I. D. (2007). Aktivitas Enzim Ligninase Isolat Pleurotus spp. Liar Asal Bogor.

https://repository.ipb.ac.id/handle/123456789/49314
Riestianti., U., Lolita, D. \& Retnani, Y. (2021). Supplementation of prill fat derived from palm oil on nutrient digestibility and dairy cow performance. American Journal of Animal and Veterinary Sciences, 16(2), 172-84. doi.org/10.3844/ajavsp.2021.172.184

Roni, P. (2018). Pemanfaatan pelepah sawit dan titonia (Tithonia diversifolia) dalam ransum kambing peranakan etawa untuk menunjang program swasembada SUSU 2020 (Doctoral dissertation, Universitas Andalas). http://scholar.unand.ac.id/40170/

Routa, S. N., Hilakore, M. A., \& Dato, T. O. D. (2015). Kecernaan bahan kering dan bahan organik secara in vitro limbah kelapa muda hasil biokonversi jamur tiram putih (pleurotus ostreatus) dengan dosis inokulum dan lama inkubasi yang berbeda. jurnal nukleus peternakan, 2(1), 103-109. doi.org/10.35508/nukleus.v2i1.738

Samadi, S., Wajizah, S., Usman, Y., Riayatsyah, D., \& Al Firdausyi, Z. (2016). Improving sugarcane bagasse as animal feed by ammoniation and followed by fermentation with Trichoderma harzianum (in vitro study). Animal Production, 18(1), 14-21. doi.org/10.20884/1.anprod.2016.18.1.516.

Satter, L. D., \& Slyter, L. L. (1974). Effect of ammonia concentration on rumen microbial protein production in vitro. British journal of nutrition, 32(2), 199-208. doi.org/10.1079/bjn19740073

Shaba, A. M., \& Baba, J. (2012). Screening of Pleurotus ostreatus and Gleophylum sepiarium strains for extracellular protease enzyme production. Bayero Journal of Pure and Applied Sciences, 5(1), 187-190. https://www.ajol.info/index.php/bajopas/article/view 180962

Steel, R. G. D., \& Torrie, J. H. (1960). Principles and procedures of statistics. Principles and procedures of statistics.

https://www.cabdirect.org/cabdirect/abstract/1961 1601129

Suharnowo, S. L., Pramana, B., \& Isnawati. (2012). Pertumbuhan miselium dan produksi tubuh buah jamur tiram putih (Pleurotus ostreatus) dengan memanfaatkan kulit ari biji kedelai sebagai campuran pada media tanam. LenteraBio, 1(3), 125-30. https://jurnalmahasiswa.unesa.ac.id/index.php/lenter abio/article/view/414

Susanti, D., Jamarun, N., Agustin, F., Astuti, T., \& Yanti, G. (2020). Kecernaan in-vitro fraksi serat kombinasi pucuk tebu dan titonia fermentasi sebagai pakan ruminansia. Jurnal Agripet, 20(1), 86-95. doi.org/10.17969/agripet.v20i1.16040 
Suyitman, W. L., Rahmat, A., \& Pazla, R. (2020). Digestibility and performance of beef cattle fed ammoniated palm leaves and fronds supplemented with minerals, cassava leaf meal and their combinations. Adv. Anim. Vet. Sci, 8(9), 991-996. doi.org/10.17582/journal.aavs/2020/8.9.991.996

Tilley, J. M. A., \& Terry, D. R. (1963). A two-stage technique for the in vitro digestion of forage crops. Grass and forage science, 18(2), 104-111. doi.org/10.1111/j.1365-2494.1963.tb00335.x

Warishi, H., Valli, K., \& Gold, M. H. (1992). Manganese (II) oxidation by manganese peroxidase from the basidiomycete Phanerochaete chrysosporium. Kinetic mechanism and role of chelators. Journal of biological chemistry, 267(33), 23688-23695.

https://pubmed.ncbi.nlm.nih.gov/1429709/
Yakin, EA, \& Mulyono, AMW (2017). The Effect of Fermentation Time on Enzyme and Lignin Activities in Cocoa Peel Fermentation Process Using Phanerochaete chrysosporium Mold. Agrisaintifika: Journal of Agricultural Sciences, doi.org/10.32585/ags.v1i2.51a

Yanti, G., Jamarun, N., \& Astuti, T. (2021, June). Quality Improvement of Sugarcane Top as Animal Feed with Biodelignification by Phanerochaete Chrysosporium Fungi on In-vitro Digestibility of NDF, ADF, Cellulose and Hemicellulose. In Journal of Physics: Conference Series (Vol. 1940, No. 1, p. 012063). IOP Publishing. doi.org/10.1088/1742-6596/1940/1/012063

Zhang, Z., Xia, L., Wang, F., Lv, P., Zhu, M., Li, J., \& Chen, K. (2015). Lignin degradation in corn stalk by combined method of $\mathrm{H}_{2} \mathrm{O}_{2}$ hydrolysis and Aspergillus oryzae CGMCC5992 liquid-state fermentation. Biotechnology for biofuels, 8(1), 1-14. doi.org/10.1186/s13068-015-0362-4.8 